\title{
Reninlike Activity in Kidneys of Rats with Various Types of Experimental Hypertension
}

\author{
Yoshiaki Masuyama, M.D., * Rihei Sato, M.D., * Yogo Yamanaka, M.D., * \\ Yukiko Ohno, M.D., * Sho Tanaka, M.D., * Tadashi Murata, M.D., ** \\ and Hiroshi SuzukI, M.D.**
}

Renal pressor activity was measured in rats with the different types of experimental hypertension using a direct method for the evaluation of the role of the renal pressor material in the production and the maintenance of high blood pressure. Renin content was increased in the constricted kidney and decreased in the contralateral of renal hypertension, and also decreased in adrenal regeneration hypertension. In coarctation of aorta and neurogenic hypertension, renin content in the kidneys was within normal range. High blood pressure could be maintained independently of an increase in renin concentration of the kidneys. Renal renin content seems likely the result of the sodium situation of animals and the circulation in one kidney, It still remains possible that a small change in renin formation and secretion, not detectable by the present method, might affect the reactivity of the vascular smooth muscle to the sympathetic neurohumoral agent.

$\checkmark H E$ possible role of renin as a causative agent in experimental renal hyper1 tension has been extensively investigated. Measurements of the renin content of kidneys of animals with experimental renal hypertension have yielded many conflicting results. $\left.\left.\left.{ }^{2}(-6), 9\right), 10\right), 12\right), 13$ )

In our previous work, it was supposed that the small amounts of renin, consequently angiotensin, secreted from the affected kidney might influence the vascular hyperreactivity to the sympathetic neurohumoral agent in chronic renal hypertension. ${ }^{14), 15)}$

The direct experimental approach, the measurement of the circulating pressor agent, still continues to present the technical difficulties of sampling, chemical identification and assay because of its minute amounts. Therefore, it was considered desirable to assay the renal pressor activity by means of a direct and reproducible method in the various types of experimental hyper-

* From the First Department of Internal Medicine, Faculty of Medicine University of Tokyo, Tokyo.

* From the Second Department of Internal Medicine, Showa Medical College, Tokyo.

Received for publication August 4, 1966. 
tension for the evaluation of the significance of renal pressor material in hypertension.

The present report concerns the renal pressor activity of rats with different types of hypertension, including renal hypertension due to unilateral renal artery constriction, aortic coarctation, adrenal regeneration and neurogenic hypertension.

\section{Methods}

\section{Production of experimental hypertension}

Female Wistar rats were made hypertensive by the following procedures:

(group A) Renal hypertension was produced in 5 rats weighing about 100-150 $\mathrm{Gm}$. by clamping the left renal artery with a silver clip $0.2 \mathrm{~mm}$. wide, leaving the right kidney intact.

(group B) Coarctation of the aorta was produced by applying a silver clip of $0.8 \mathrm{~mm}$. diameter according to the method of Nolla-Panades. ${ }^{16)}$ In group $\mathrm{B}_{1}$ ( 7 animals) the clip was applied just above the origin of both main renal arteries and in group $\mathrm{B}_{2}$ (4 animals) it was placed below the origin of both renal arteries.

(group $\mathrm{G}$ ) Adrenal regeneration hypertension was produced by adrenal enucleation in 5 rats weighing about $80-100 \mathrm{Gm}$. by the technique of Ingle and Higgins. ${ }^{17}$ ) Experimental animals were unilaterally nephrectomized (right), unilaterally adrenalectomized (right) followed by enucleation of left adrenal. These rats were given $1 \%$ saline as drinking fluid after operation.

(group D) Neurogenic hypertension was made in 5 rats weighing about $200-$ $250 \mathrm{Gm}$. by sino-aortic baroreceptor denervation by the method of Krieger. ${ }^{19)}$ The aortic depressor fibers were interrupted at the neck level by resecting aortic nerves, cervical sympathetic trunks and superior laryngeal nerves. The carotid sinus was denervated by stripping the carotid bifurcation and painting with $10 \%$ phenol in ethanol.

Arterial pressure was estimated by a microphonic method prior to and at weekly intervals after operation under light ether anesthesia.

\section{Extraction of rat renal pressor material}

The kidneys were removed under pentobarbital anesthesia of its pelvis and peripelvic fat, the tissue was minced with scissors and ground with pestle in a mortar adding about $0.3 \mathrm{Gm}$. of sand. Isotonic saline was added in the ratio of $1 \mathrm{ml}$./ $100 \mathrm{mg}$. tissue. The mixture was stirred for $10 \mathrm{~min}$. at room temperature. The homogenate was then centrifuged $10 \mathrm{~min}$. at $2000 \mathrm{rpm}$ and the supernatant fluid was used for determination of the pressor activity.

\section{Bioassay of pressor activity}

The assay of pressor activity in the extract was performed on rats, weighing $150-200 \mathrm{Gm}$. They were anesthetized with sodium pentobarbital $(4 \mathrm{mg} . / 100 \mathrm{Gm}$., intraperitoneally), sensitized with pentolinium (5 mg., subcutaneously with $0.2 \mathrm{Gm}$. of PVP) and vagotomized. A tracheal cannula was inserted. Blood pressure from a cannulated carotid artery was recorded by a mercury manometer on the 


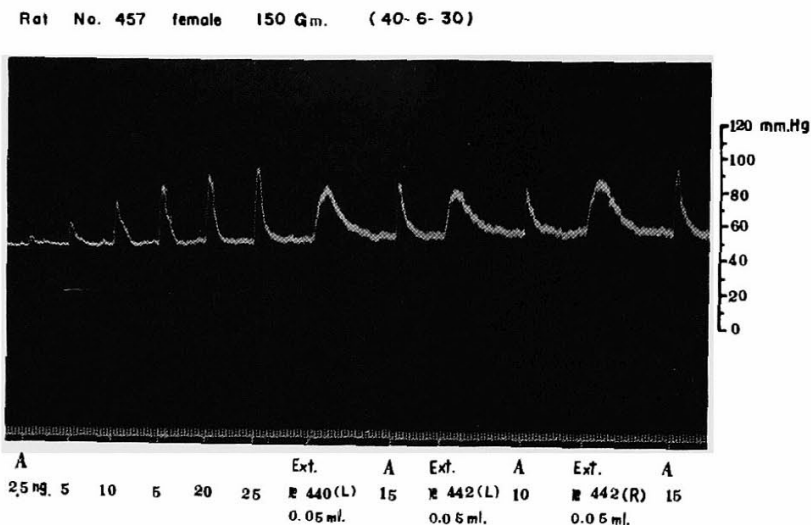

Fig. 1 .

smoked paper. Pressor activity in the extracts was estimated from the maximum rise in arterial pressure. The height of pressor responses was referred to that of synthetic angiotensin II (Fig. 1). Results were expressed in micrograms of angiotensin per $\mathrm{Gm}$. of fresh kidney tissue.

It is probable that the pressor activity in the extracts was due to renin, because the pressor responses were similar in shape and duration to that produced by purified hog renin, and the activity was unchanged after dialysis of the extract, though it was eliminated by heating the extract for $10 \mathrm{~min}$. at $80^{\circ} \mathrm{C}$.

\section{RESUlts}

Pressor activity in kidneys of normal rats

Table I shows the values for pressor activity in saline extracts of 20 normal

Table I. Reninlike Activity in Normal Rat Kidneys

\begin{tabular}{c|c|c|c}
\hline Rat No. & Pressor activity* & Rat No. & Pressor activity \\
\hline $488 \mathrm{a}^{* *}$ & 8.0 & $498 \mathrm{~b}$ & 6.0 \\
$488 \mathrm{~b}^{* *}$ & 7.0 & $442 \mathrm{a}$ & 2.3 \\
$479 \mathrm{a}$ & 1.4 & $442 \mathrm{~b}$ & 2.1 \\
$447 \mathrm{a}$ & 2.6 & $445 \mathrm{a}$ & 1.8 \\
$464 \mathrm{a}$ & 1.5 & $445 \mathrm{~b}$ & 1.4 \\
$435 \mathrm{a}$ & 1.8 & $594 \mathrm{a}$ & 3.6 \\
$435 \mathrm{~b}$ & 3.5 & $597 \mathrm{a}$ & 3.2 \\
$474 \mathrm{a}$ & 2.0 & $581 \mathrm{a}$ & 3.2 \\
$474 \mathrm{~b}$ & 2.0 & $576 \mathrm{a}$ & 4.6 \\
$498 \mathrm{a}$ & 6.0 & $576 \mathrm{~b}$ & 3.6 \\
& & average & $3.4 \pm 1.9$
\end{tabular}

* $\mu \mathrm{g}$. of angiotensin per Gm. of kidney

** $\mathrm{a}$ and $\mathrm{b}$ represent right and left kidney, respectively. 
rat kidneys. In normal kidneys the mean concentration of renin determined by the method corresponds to $3.4 \pm 1.9 \mu \mathrm{g}$. of angiotensin per $\mathrm{Gm}$. of fresh kidney, ranging from 8.0 to $1.4 \mu \mathrm{g}$.

\section{Pressor activity in clamped and contralateral untouched kidneys}

Table II shows the pressor activity in the clamped and unclamped contralateral kidneys of the hypertensive animals of 3 to 25 weeks duration. Pressor activity was significantly increased in the clamped kidney $(t=4.42$, $\mathrm{P}<0.001$ ), while it was definitely decreased in the untouched contralateral side $(\mathrm{t}=6.34, \mathrm{P}<0.001)$, which occurred when the blood pressure of the animals had reached or even passed the maximum elevation. Depletion of pressor activity in the untouched kidney was observed as early as 3 weeks after constriction of the left renal artery and was still present after 25 weeks. There was no observable correlation between arterial pressure and the amount of pressor activity in kidneys.

Table II. Reninlike Activity in Clamped and Contralateral Untouched Kidneys

\begin{tabular}{c|c|c|c|c|c|c}
\hline \multirow{2}{*}{ Rat No. } & $\begin{array}{c}\text { Constriction } \\
\text { of renal } \\
\text { artery }\end{array}$ & \multicolumn{2}{|c|}{$\begin{array}{c}\text { Indirect tail systolic artery } \\
\text { blood pressure }\end{array}$} & \multicolumn{2}{c}{ Pressor activity in kidneys } \\
\cline { 3 - 7 } & Preop. & \multicolumn{2}{|c|}{$\begin{array}{c}\text { Postop. } \\
\text { Clamped } \\
\text { (left) }\end{array}$} & $\begin{array}{c}\text { Unclamped } \\
\text { (right) }\end{array}$ \\
\hline 485 & $4 \mathrm{~W}$. & 100 & 199 & 170 & 30.0 & 1.0 \\
480 & $3 \mathrm{~W}$. & 114 & 146 & 118 & 7.6 & 0.2 \\
377 & $17 \mathrm{~W}$. & 84 & 167 & 120 & 3.0 & 1.8 \\
512 & $25 \mathrm{~W}$. & 97 & 112 & 194 & 16.0 & 0.5 \\
510 & $25 \mathrm{~W}$. & 92 & 186 & 175 & 6.0 & 0.6 \\
& & & & final & & \\
\end{tabular}

\section{Pressor activity in kidneys of coarctation of aorta}

Table III shows the pressor activity in kidneys of these groups. In group $B_{1}$ (coarctation above renal arteries), marked hypertension was produced in 5 of 7 animals. The mean value of the pressor activity was slightly decreased, but the decrease was not significant $(t=1.53, P<0.1)$. In group $B_{2}$ (coarctation below renal arteries), hypertension was not remarkable, while the pressor activity was slightly decreased $(\mathrm{t}=2.58, \mathrm{P}<0.01)$, probably due to its small numbers. Therefore, pressor activity in kidneys of coarctation of aorta (above or below renal arteries) was not significantly different from the control. 
Table III. Reninlike Activity in Kidneys of Coarctation of Aorta

Coarctation above renal arteries (group $B_{1}$ )

\begin{tabular}{c|c|c|c|c|c}
\hline \multirow{2}{*}{ Rat No. } & $\begin{array}{c}\text { Coarctation } \\
\text { of aorta } \\
\text { above renal } \\
\text { arteries }\end{array}$ & \multicolumn{2}{|c|}{$\begin{array}{c}\text { Direct carotid artery } \\
\text { blood pressure }\end{array}$} & \multicolumn{2}{|c}{$\begin{array}{c}\text { Pressor activity } \\
\text { in kidneys }\end{array}$} \\
\hline 443 & Preop. & Postop. (final) & left & right \\
\hline 477 & $9 \mathrm{D}$. & 105 & 130 & 3.6 & 4.6 \\
463 & $5 \mathrm{~W}$. & 90 & 215 & 2.0 & 2.7 \\
467 & $6 \mathrm{~W}$. & 90 & 165 & 2.6 & 2.8 \\
449 & $6 \mathrm{~W}$. & 100 & 220 & 1.4 & \\
440 & $8 \mathrm{~W}$. & 80 & 206 & 4.3 & 3.8 \\
446 & $3 \mathrm{~W}$. & 109 & 226 & 2.9 & 2.1 \\
& $3 \mathrm{~W}$. & 102 & 134 & 0.9 & \\
& & & average & & $2.8 \pm 1.1$
\end{tabular}

Coarctation below renal arteries (group $B_{2}$ )

\begin{tabular}{c|c|c|c|c|c}
\hline Rat No. & $\begin{array}{c}\text { Coarctation } \\
\text { of aorta } \\
\text { below renal } \\
\text { arteries }\end{array}$ & $\begin{array}{c}\text { Direct carotid artery } \\
\text { blood pressure }\end{array}$ & \multicolumn{2}{|c|}{$\begin{array}{c}\text { Pressor activity } \\
\text { in kidneys }\end{array}$} \\
\hline 434 & Preop. & Postop. (final) & left & right \\
\hline 462 & $2 \mathrm{~W}$. & 91 & 138 & 2.5 & 0.5 \\
470 & $6 \mathrm{~W}$. & 116 & 137 & 1.3 & 0.8 \\
444 & $6 \mathrm{~W}$. & 88 & 138 & 5.0 & 3.0 \\
& $9 \mathrm{D}$. & 88 & 88 & 2.8 & 1.7
\end{tabular}

Table IV. Reninlike Activity in Kidneys of Rats with Adrenal Regeneration Hypertension

\begin{tabular}{|c|c|c|c|c|c|}
\hline \multirow{3}{*}{ Rat No. } & \multirow{3}{*}{$\begin{array}{l}\text { Left adrenal } \\
\text { enucleation }\end{array}$} & \multicolumn{3}{|c|}{$\begin{array}{c}\text { Indirect tail systolic artery } \\
\text { blood pressure }\end{array}$} & \multirow{3}{*}{$\begin{array}{c}\text { Pressor } \\
\text { activity } \\
\text { in kidneys } \\
\text { (left) }\end{array}$} \\
\hline & & \multirow{2}{*}{ Preop. } & \multicolumn{2}{|c|}{ Postop. } & \\
\hline & & & $\max$. & final & \\
\hline 248 & $9 \mathrm{M}$. & 86 & 165 & 160 & 0.88 \\
\hline 242 & 9 M. $2 \mathrm{~W}$. & 65 & 192 & 192 & 0.18 \\
\hline 249 & $9 \mathrm{M}$ & 84 & 190 & 190 & 0.70 \\
\hline 290 & $8 \mathrm{M}$. & 83 & 174 & 164 & 0.80 \\
\hline \multirow[t]{2}{*}{296} & $7 \mathrm{M}$ & 80 & 184 & 164 & 0.86 \\
\hline & & & & average & $0.68 \pm 0.26$ \\
\hline
\end{tabular}

Pressor activity in kidneys of rats with adrenal regeneration hypertension

Table IV shows the pressor activity in kidneys with adrenal regeneration hypertension for 7 to 9 months duration. Sustained hypertension was pro- 
duced in all animals. There was a consistent decrease in pressor activity in these kidneys $(t=6.34, P<0.001)$, only one fifth of the value for normal rats kidneys.

\section{Pressor activity in kidneys of rats with neurogenic hypertension}

Table $\mathrm{V}$ presents the values for pressor activity in kidneys of rats with neurogenic hypertension of 2 to 14 weeks duration. The average was $2.7 \pm$ $1.3 \mu \mathrm{g}$. of angiotensin $/ \mathrm{Gm}$. of kidney. This value was not significantly different from the average of controls $(t=1.50, P<0.1)$. Renal vascular changes in these kidneys will be described in detail elsewhere.

Table V. Reninlike Activity in Kidneys of Rats with Neurogenic Hypertension

\begin{tabular}{|c|c|c|c|c|c|}
\hline \multirow{3}{*}{ Rat No. } & \multirow{3}{*}{$\begin{array}{l}\text { Sino-aortic } \\
\text { baroreceptor } \\
\text { denervation }\end{array}$} & \multicolumn{3}{|c|}{$\begin{array}{c}\text { Indirect tail systolic artery } \\
\text { blood pressure }\end{array}$} & \multirow{3}{*}{$\begin{array}{c}\text { Pressor } \\
\text { activity } \\
\text { in kidneys }\end{array}$} \\
\hline & & \multirow{2}{*}{ Preop. } & \multicolumn{2}{|c|}{ Postop. } & \\
\hline & & & $\max$ & final & \\
\hline $536 a$ & $2 \mathrm{~W}$. & 84 & 92 & 92 & 2.4 \\
\hline $478 a$ & $10 \mathrm{~W}$. & 84 & 165 & 160 & 3.5 \\
\hline $416 a$ & $14 \mathrm{~W}$ & 101 & 120 & 96 & 0.9 \\
\hline $414 a$ & $14 W$ & 96 & 120 & 120 & 3.8 \\
\hline $417 a$ & $14 \mathrm{~W}$. & 96 & 152 & 130 & 4.2 \\
\hline \multirow[t]{2}{*}{$417 b$} & $14 \mathrm{~W}$. & 96 & 152 & 130 & 1.2 \\
\hline & & & & average & $2.7 \pm 1.3$ \\
\hline
\end{tabular}

\section{Discussion}

Our results for normal rat kidneys demonstrate a fairly wide range. The assay method used in these experiments is relatively simple and yields quantitative and reproducible results. It avoids purification procedures and the associated possibilities of loss of pressor material. It also avoids the interfering action of depressor material in the extract. The kidney extract of rats produced effects without an initial decline in blood pressure of the test animals by this method. The renin concentration as determined by the direct and indirect methods was in satisfactory agreement. As the groups, rats made hypertensive by constricting a renal artery showed an increase in reninlike activity in the clamped kidney. On the other hand, the contralateral untouched kidneys contained lower amounts of renin than the kidneys of normotensive animals. However, in individual animals there was no correlation between the amount of pressor activity and the level of the arterial pressure. Reninlike activity of 
the kidneys was also not related to the duration of hypertension, as far as 3 to 25 weeks, similar to those shown by Brunner et al. ${ }^{11}$

Thus, a humoral factor, presumably of renal origin, is more important than systemic arterial pressure in determining the amount of pressor material in the kidney, as supported by Bliddal, Masson and McCubbin. ${ }^{4)}$

Although in the presence of both kidneys there is an increase in renin concentration in the clamped kidney, total renin content does not always exceed normal values, as the reduction in the unclamped kidney approximately compensates for the higher amount in the clamped kidney.

In coarctation of aorta, hypertension occurred definitely only if the clamp was applied above the main renal arteries. However, the reninlike activity in kidneys of animals with coarctation of aorta did not change up to 8 weeks, as in the case of unilaterally nephrectomized rats bearing a clip on the artery of the remaining kidney. ${ }^{91,101,13)}$

A definite diminution of renin activity was found in kidneys of rats with adrenal regeneration hypertension. It was reported that in rats in which hypertension had been produced by overdosage of cortexone or DCA and salt, pressor activity disappeared from the kidneys. ${ }^{71,11)}$ It was indicated that renin formation and secretion were most likely the result of the sodium state of the animals. ${ }^{9)}$

The amount of pressor activity in kidneys was normal in rats with neurogenic hypertension, as indicated in $\operatorname{dogs}^{4)}$ and rabbits, ${ }^{5)}$ accounted for by the fact that this type of hypertension is often considered to be labile.

Thus, renin content was increased in the constricted kidney and decreased in the contralateral of renal hypertension, and also decreased in adrenal regeneration hypertension. In coarctation of aorta and neurogenic hypertension, renin concentration in the kidneys was within normal range. High blood pressure, therefore, could be maintained independently of an increase in renin concentration of the kidneys. It seems also likely the result of the sodium balance of the animals and the renal circulation in one kidney. However, it still remains possible that a small change in renin formation and secretion, not detectable by the present method, might affect the reactivity of the vascular smooth muscle to the sympathetic neurohumoral agent.

\section{SUMMARY}

Reninlike activity in rat kidneys was measured using a simple but reliable procedure that involved giving saline extracts of portions of renal tissues into the sensitized assay rats.

(1) Clamping one renal artery caused an increased concentration of 
renin in the clamped kidney and a fall in the contralateral untouched kidney.

(2) Coarctation of aorta above the main renal artery induced marked hypertension, but did not result in an increase in renin concentration of the kidneys.

(3) Renin content was definitely diminished in kidneys of rats with adrenal regeneration hypertension.

(4) In rats with neurogenic hypertension the amount of pressor material in kidneys was within the normal range.

High blood pressure may, therefore, be maintained independently of an increase in renin concentration of the kidneys.

\section{References}

1. Harrison, T. R., Blalock, A., Mason, M. F., and Williams, J. R. : Arch. Int. Med. 60: 1058, 1937.

2. Taquini, A. C., Blaquier, P., and Taquini, A. C., Jr.: Circulation $17: 672,1958$.

3. Haas, E. and Goldblatt, H. : Am. J. Physiol. 197: 1103, 1959.

4. Bliddle, J., Masson, G. M. C., and McCubbin, J. W.: Am. J. Physiol. 208 : 1078, 1965.

5. Sirotina, M. F.: Federation Proc. 22: T 1127, 1963.

6. Masson, G. M. C.: Experientia 18: 243, 1962.

7. Gross, F. and Sulser, F.: Arch. exp. Path. Pharmakol. $229: 374,1956$.

8. Gross, F. and Lichtlen, P.: Proc. Soc. Exp. Biol. \& Med. 98 : 341, 1958.

9. Fisher, E. R., Tamura, M., and Masson, G. M. C.: Proc. Soc. Exp. Biol. \& Med. 118 : $1191,1965$.

10. Regoli, D., Brunner, H., Peters, G., and Gross, F.: Proc. Soc. Exp. Biol. \& Med. 109 : 142, 1962.

11. Brunner, H., Desaulles, P. A., Regoli, D., and Gross, F.: Am. J. Physiol. 202 : 795, 1962.

12. Blaquier, P., Bohr, D. F., Taquini, A. C., Jr., and Hoobler, S. W.: Proc. Soc. Exp. Biol. \& Med. 108: 711,1961 .

13. Regoli, D., Hess, R., Brunner, H., Peters, G., and Gross, F.: Arch. int. Pharmacodyn. 145 : 416, 1962.

14. Masuyama, Y.: Jap. J. Nephrol. 7: 23, 1955.

15. Masuyama, Y.: Jap. Circulat. J. $30: 182,1966$.

16. Nolla-Panades, J.: Circulat. Res. $12: 3,1963$.

17. Ingle, D. J. and Higgins, M. : Am. J. Med. Sci. $196: 232,1938$

18. Krieger, E. M.: Circulat. Res. 15: 511, 1964. 